\title{
The Influence of Social Dimension, Financial Flexibility Dimension and Environmental Dimension (Triple Bottom Line) on The Management Accounting Information System in Regional General Hospitals in East Java Province
}

\author{
Ontot Murwato Suwondo \\ Department of Accounting, \\ University of 17 Agustus 1945 Surabaya, Indonesia \\ Tri Ratnawati \\ Department of Accounting, \\ University of 17 Agustus 1945 Surabaya, Indonesia \\ Widodo J. Pudjirahardjo \\ Faculty of Public Health, \\ University of Airlangga Surabaya, Indonesia \\ Mulyanto Nugroho \\ Department of Accounting, \\ University of 17 Agustus 1945 Surabaya, Indonesia
}

\begin{abstract}
The core of Management Accounting Information System (MAIS) is a process; determined by activities such as collecting, measuring, storing, analyzing, reporting, and managing information. MAIS is useful for decision making and performance evaluation in manufacturing companies, trading and service. Today, wise business is the one that balances the financial, social and environmental aspects (Triple Bottom Line/TBL). Based on this phenomenon, the study entitled The Influence of Social Dimension, Financial Flexibility Dimension and Environmental Dimension (Triple Bottom Line) on the Management Accounting Information System in Regional General Hospitals in East Java Province was conducted. The population in this study was 183 work units in 4 (four) Regional General Hospitals (RSUD) of East Java Provincial Government. This research belongs to the positivism paradigm, thus hypothesis testing is an important stage. SPSS was employed to test the validity and reliability of the questionnaire. For the model (outer and inner model) testing and hypothesis testing, Variance-Based SEM, PLS (smart PLS 3.0) was used. Hypothesis test results showed that: 1) The financial dimension had a significant effect on MAIS; 2) The financial flexibility dimension had a significant effect on MAIS; 3) The environmental dimension had a significant effect on MAIS.
\end{abstract}

Keywords: MAIS (Management Accounting Information System), Management Accounting System for Hospitals (MASH), Triple Bottom Line (TBL), RSUD (Regional General Hospital).

\section{INTRODUCTION}

According to [1], management accounting is conducted for specific requirement of decision maker and it's rarely distributed to outsiders. Management Accounting plays a strategic role in the management of business entities both profit and non-profit oriented such as hospital entities. Hospital entities, both private and government hospital, are known as complex entities in the fields of human resources, technological resources, finance and community demands for 
Suwondo, O. M., Ratnawati, T., Pudjirahardjo, W. J., \& Nugroho, M. (2018). The Influence of Social Dimension, Financial Flexibility Dimension and Environmental Dimension (Triple Bottom Line) on The Management Accounting Information System in Regional General Hospitals in East Java Province. Archives of Business Research, 6(12), 81-89.

the comprehensive health services. Like in Indonesia, hospital or health care entities in many countries also have complex problems, and it has always been a special concern for the government [2]. Based on [3], in his article explains that hospitals with traditional systems, especially in the government sector, cannot provide timely and meaningful information needed to meet management's needs. In the public sector, the hospitals have almost no useful information for management.

As happened in Indonesia, especially in other developing countries, hospital expenditures usually reach 50 to 80 percent of the total routine expenditure of the government health sector. The significant allocation of funds in the health sector is a reflection of the implementation of the mandate of Law Number 36 of 2009 concerning Health. Article 3 of Law Number 36 of 2009 explains that health development aims to increase awareness, willingness and ability to live healthy for everyone in order to realize the highest degree of public health, as an investment for the development of productive human resources socially and economically.

The Indonesian government issued several supporting regulations including PERMENDAGRI 61 of 2007 concerning the Financial Management Pattern of Regional Public Service Agencies (PPK-BLUD). PPK-BLUD aims to improve the quality of service to the community, based on good financial management of sound, effective and efficient business concept.

As a part of the success of the BLUD-RSUD in implementing sound business practices, management accounting plays a very strategic role. Supporting this statement, it is stated that the need of management accounting information is not limited to manufacturing organizations; the information is also used in trading companies, service companies and even non-profit organizations [4]. According to [5], in their research entitled Hospital Management Support Through The Use of Management Accounting state that "the role of management accounting in medical care is very important". Based on [3], from the Department of Psychiatry, University of Cape Town, in his article explains that hospitals with traditional systems, especially in the government sector, cannot provide timely and meaningful information needed to meet management's needs. In the public sector, hospitals have almost no useful information for management.

The traditional approach measures the performance of companies, especially the profitoriented ones, prioritizing the financial aspects. In its development, it is proven that if financial aspects are the only indicator of success, there will be distortion. Eventually, the company will lose the trust from community. Stakeholders, both the government as the regulator and the public as consumers, are increasingly aware that good and ethical business is a wise business. Wise business mean a business that balances financial, social and environmental aspects. The three aspects including financial, social and environmental aspects in the business world is known as the Triple Bottom Line (TBL), as stated by its creator [6]. Based on [6] believes that companies that want to operate sustainably must pay attention to "3Ps". In addition to pursuing profits, companies must also pay attention to the welfare of the people and the company must also actively provide support for environmental sustainability (planet). Supporting Elkington's theory, according to [7], suggest that a company is a member/ part of the moral community, which must provide social responsibility. This theory focuses on sustainability, and requires each company to consider its activities in three independent scales; economic sustainability, social sustainability, and environmental sustainability. Many parties state that entities that pay attention to environmental quality will be able to build sustainable 
businesses. According to [4] stated that Environmental performance can have a significant effect on a firm's financial position.

Previous research on the effects of exogenous CSR / social and environmental variables on the financial performance of a company or CFP (corporate financial performance) have been done repeatedly, as well as research on the effect of financial flexibility on company performance. However, research on variables of social dimension, financial flexibility and environmental dimensions (Triple bottom Line) on Management Accounting Information system (MAIS) still cannot be found. Some of the previous studies, although they are not of quite relevant to this study, have yielded mixed findings. Some indicated significant effect, some were insignificant and others indicated no effect. Some of results of previous studies are presented as follows: 1) According to [8] in his research entitled The relationship between CSR and financial performance explained that the relationship between CSR variables and financial performance variables in trading companies in Sweden in 2006-2009, was not significant, 2) Based on [9], in a research entitled The Impact of Corporate Social Responsibility on Firms' Financial Performance in South Africa concluded that based on these results, we find that CSR activities lead to no significant differences in financial performance, 3) According to [10] in a study "Financial Management Practices and Their Impact on Organizational Performance" showed that there was a positive and significant relationship between financial management practices and organizational performance, 4) Based on [11] conducted a study entitled An Empirical Analysis of Effects on Firms' Economic Performance of Implementing Environmental. This paper investigated whether the application of an environmental management system (EMS) influenced company added value, 5) [12] in a study entitled The Effect of Environmental Performance on Corporate Financial Performance with Corporate Social Responsibility (CSR) Disclosure as Intervening Variables concluded that environmental performance variables did not affect economic performance.

Based on this background, then the researchers were interested to conduct a research with the title "The Influence of Social Dimension, Financial Flexibility Dimension and Environmental Dimension (Triple Bottom Line) on the Management Accounting Information System in Regional General Hospitals in East Java Province".

\section{Management Accounting Information System}

\section{LITERATURE REVIEW AND HYPOTHESES}

Management accounting information system hereinafter referred as MAIS, provides information needed to achieve specific objectives for management. The essence of the Management Accounting Information System (MAIS) is a process, which is determined by activities such as collecting, measuring, storing, analysing, reporting, and information management [4]. MAIS is an information system that processes inputs to produce output in the form of specific reports such as; reports on product costs, customer costs, budgets, performance reports and more. The management accounting system that is specifically implemented to meet management information in a hospital entity is known as Management Accounting System For Hospital (MASH). Based on [13], explained that MASH is a framework for tracking and analyzing a health facility's services, resources, and costs. It provides a means for both routine management control and initiation and management of change. It is a useful tool for examining costs in connection with productive efficiency.

According to [5], in a research entitled Hospital Management Support Through The Use of Management Accounting suggest that "the role of management accounting in medical care institutions is very important". 
Suwondo, O. M., Ratnawati, T., Pudjirahardjo, W. J., \& Nugroho, M. (2018). The Influence of Social Dimension, Financial Flexibility Dimension and Environmental Dimension (Triple Bottom Line) on The Management Accounting Information System in Regional General Hospitals in East Java Province. Archives of Business Research, 6(12), 81-89.

\section{Triple Bottom Line}

Traditional approaches measure the success of companies, especially profit-oriented ones, by prioritizing the financial aspects. Companies that are able to get high profits are called successful. The development of the business world shows that if financial aspects are the only indicator of success, distortions occur and in the long run the company will lose the trust of the wider community. Stakeholders are increasingly aware that good business, which is ethical, is a wise business which means a business that balances both financial, social and environmental aspects. Based on [6] states that companies that want to operate sustainably should pay attention to "3Ps". In addition to pursuing profits, companies must also pay attention to the fulfillment of people's welfare (people) and companies must also actively support the preservation of environmental quality (planet). According to [14], states that "reporting on economic, environmental and social performance by all organizations is as routine and comparable as financial reporting scheme of sustainable development: at the confluence of Three Constituent Parts".

\section{Social Dimension}

The first research variable is the social dimension. It is an activity or hospital program in the social field, which is explained by the following theory/concept:

1) According to World Business Council of Sustainability Development, Corporate Social Responsibility (CSR) is implemented to improve the quality of life in workplaces and their families as well as the local community and the wider community.

2) The Decree of the Minister of Health of the Republic of Indonesia Number 1087/ MENKES/SK/VIII/2010 concerning Occupational Health and Safety Standards at the Hospital explains that Hospital Human Resources (HR), visitors, patients and communities around hospitals want protection from health problems and work accidents, both as a result of the process of providing service activities because of the availability of facilities and infrastructure in hospitals that do not meet the standards.

3) Law No. 36 of 2009 concerning Health states that Hospitals must guarantee occupational health and safety for patients, service providers or workers and the surrounding community from various potential hazards in the Hospital.

\section{Dimensions of Financial Flexibility}

Financial flexibility is related to financial management. "Financial management is the name of planning, directing, monitoring, organizing, and controlling the monetary resources of an organization" (Mustafa Shah, 2015). In this study, financial flexibility is the flexibility given to BLUD to manage the financial/goods at certain limits which can be excluded from generally accepted provisions [15]. Financial flexibility is intended as specificity or flexibility to apply sound business practices to improve service for the community. Financial flexibility, among others, is measured by the company's liquidity as carried out by [16], in a study entitled the relation between financial flexibility and financial performance in Tehran listed firms. They conclude that the financial flexibility variable (as measured by liquidity) is significantly related to company performance. The dimensions of financial flexibility are also measured by indicators like the easiness of paying health costs and flexibility in preparing financial statements.

\section{Environmental Dimensions}

Management of the hospital environment is defined as a systematic and integrated efforts carried out to preserve environmental functions and prevent pollution and/or environmental damage which include planning, utilization, control, maintenance, supervision and law 
enforcement [17]. The International Federation of Accountants (1998) states that Environmental Management Accounting is the development of Environmental Management and all of the company's economic performance and the implementation of the right environment in the relationship between the Accounting System and its practice. The application of Environmental Management Accounting to businesses or activities simultaneously can improve economic performance and environmental performance. According to [4] state that environmental cost reports are information related to the relative distribution of environmental costs, which are useful for improving and controlling environmental performance. A good environmental cost report provides detail environmental costs by category. Research on environmental dimensions uses indicators like waste treatment plant facilities, hygiene facilities and parks, and sanitation facilities.

\section{Hospital Entity}

Hospital is a health service institution that organizes individual health services in a comprehensive manner that provides inpatient, outpatient, and emergency services (Law No.44, 2009). The limits of hospitals are an organized professional medical personnel organization and permanent medical facilities in carrying out medical services, continuous nursing care, diagnosis, and treatment of diseases suffered by patients. Based on [18] stated that the hospital is not only a place but also a facility, an institution, and an organization, which has a special atmosphere. According to [19] argues that to realize a good management of a health institution (hospital), a hospital manager is faced with two task domains; internal and external. Internal domains concern the day-to-day tasks of managers related to health services, finance and HR issues, all of which are problems under the control of the managers. External domains are related to the influence of resources and activities that occur outside the organization and are thus beyond the control of the managers such as population growth, government policies and others. In the past few decades, the health care industry has become business people's favorite, especially the private sector.

\section{Regional Public Service Agency}

Permendagri number 61 of 2007 explains that the Regional Public Service Agency, hereinafter abbreviated as BLUD, is the Regional Work Unit or Work Unit in the Regional Work Unit within the regional government. BLUD is formed to provide goods and/or services which are sold without prioritizing profit, and carry out their activities based on the principles of efficiency and productivity. The BLUD is formed with the aim of improving the quality of services to the public based on sound business practices. To support the achievement of BLUD performance, certain flexibility is given such as: management of cash, accounts receivable, investment and others, responsibly.

\section{Hypothesis and Model Analysis}

1. The social dimension of the hospitals has a significant effect on MAIS BLUD in Regional General Hospitals in East Java Province;

2. The financial flexibility dimension of the hospitals has a significant effect on MAIS BLUD in Regional General Hospitals in East Java Province;

3. The environmental dimension of the hospitals has a significant effect on MAIS BLUD in Regional General Hospitals in East Java Province; 


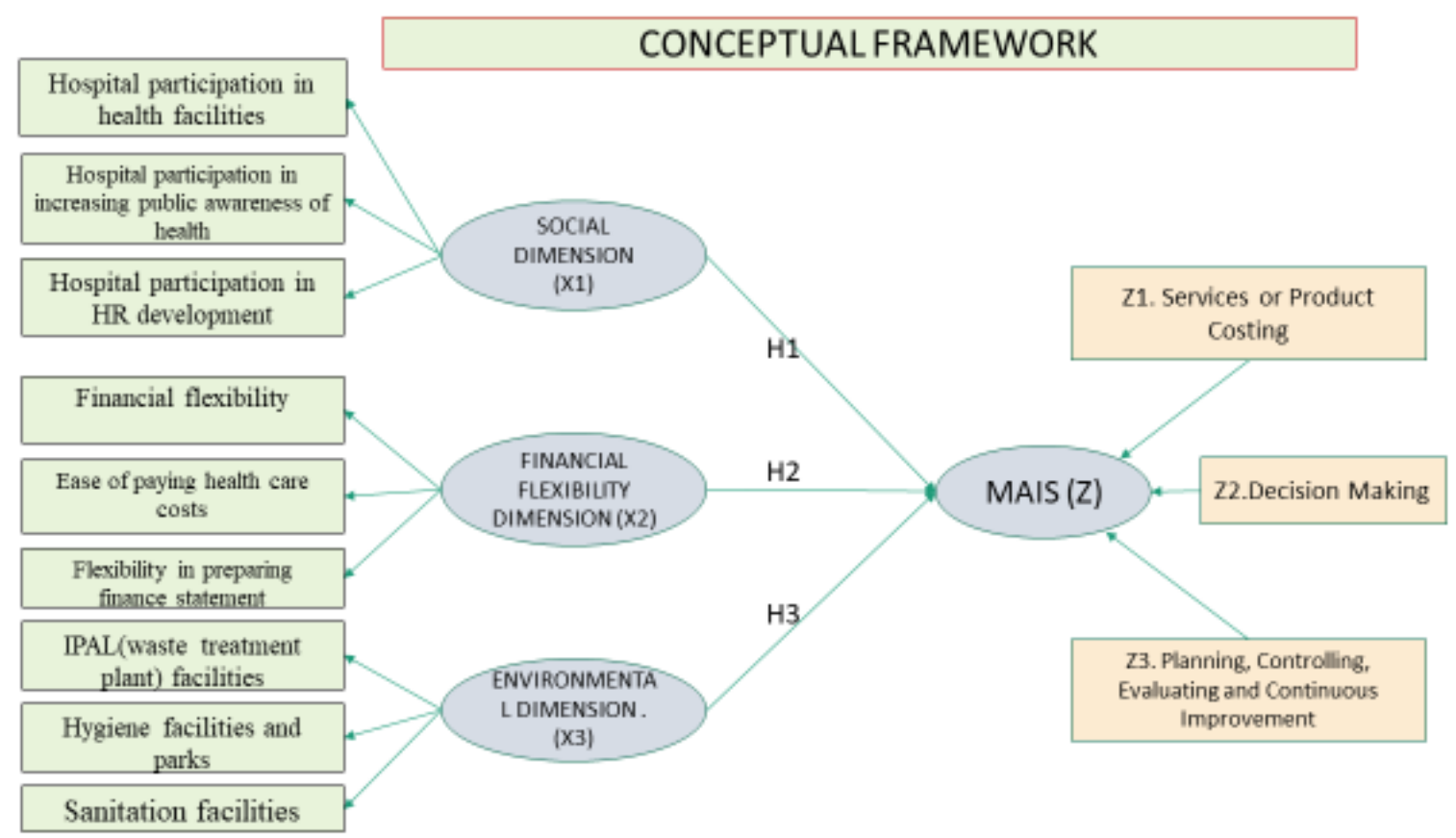

Figure 1. Model Analysis

\section{Definition of Financial Report Analysis}

RESEARCH METHODS

The study was conducted at 4 (four) general hospitals in East Java Province that had implemented the Financial Management Pattern of the Regional Public Service Agency (PPKBLUD). The four hospitals consisted of 2 Class A Education hospitals and 2 Class B Education hospitals. The number of work units at the Regional General Hospitals was 183 work units, consisting of Sub-Department, Sub-Section and Installation. The number of work units was as the population as well as the samples. In accordance with its characteristics, research data on independent variables X1, X2 and X3 and MAIS are processed and analyzed using SPSS and Variance-Based SEM, PLS. PLS (Partial Lease Square) is powerful analysis method because it is not based on many assumptions [20]. In PLS, there are two main parts, namely the measurement model (outer model) and structural model (inner model). Outer model is used to analyze and test the validity and reliability of indicators on each variable, while inner model is used to analyze and test causality relationships between variables [21].

\section{CONCEPTUAL FRAMEWORK}

Before testing the model, the validity and reliability tests are carried out with the help of SPSS. Social dimension, financial flexibility dimension and environmental dimension consist of 3 indicators with 9 statements for each indicator. It was concluded that the questionnaire items on the variables of social dimension, financial flexibility dimension and environmental dimension were valid and reliable, as evidenced by significant values $0.001(<5 \%)$ and the cronbach's alpha value of 0.60 or greater.

The research hypothesis is proven by the significant level of influence between variables. The inner model in PLS is evaluated using $\mathrm{R}^{2}$ for the dependent construct, and the path coefficient value or t-value (t-statistics) for the test of significance between constructs. The higher the value of $\mathrm{R}^{2}$ is the better the prediction of the model proposed. The score for the path or inner 
model coefficient shown by the value t-statistics must be above 1.96 for testing hypotheses on alpha (level of research error) of 5\% [21].

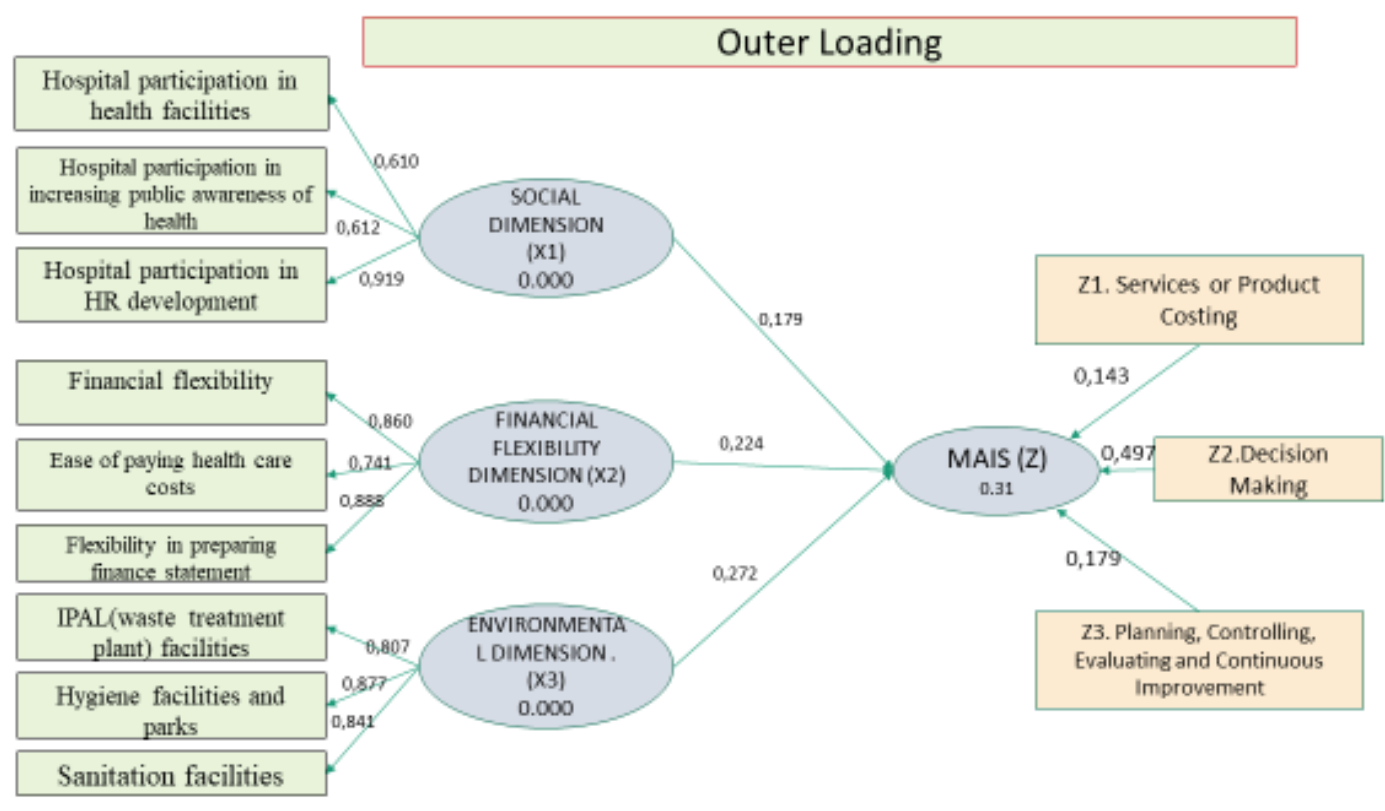

Figure 2. Algorithm Bootstrapping report

Table 1. Path of Coefficients (Mean, STDEV, t-Values)

Path Coefficients (Mean, STDEV, T-Values)

\begin{tabular}{|c|c|c|c|c|c|}
\hline & $\begin{array}{c}\text { Original } \\
\text { Sample } \\
\text { (0) }\end{array}$ & $\begin{array}{c}\text { Sample } \\
\text { Mean } \\
\text { (M) }\end{array}$ & $\begin{array}{c}\text { Standard } \\
\text { Deviation } \\
\text { (STDEV) }\end{array}$ & $\begin{array}{c}\text { Standard } \\
\text { Error } \\
\text { (STERR) }\end{array}$ & $\begin{array}{c}\text { T Statistics } \\
\text { (O / STERR) }\end{array}$ \\
\hline $\begin{array}{c}\text { FINANCIAL FLEXIBILITY -> } \\
\text { MAIS }\end{array}$ & 0.224172 & 0.229296 & 0.089401 & 0.089401 & 2,507494 \\
\hline ENVIRONMENT -> MAIS & 0.272144 & 0.282335 & 0.080286 & 0.080286 & 3,389668 \\
\hline SOCIAL -> MAIS & 0.178947 & 0.194086 & 0.086872 & 0.086872 & 2,059892 \\
\hline
\end{tabular}

Path Coefficient, the level of significance of the relationships between variables in the research and the results are stated as follows:

$\mathbf{H}_{\mathbf{1}}$ The influence of the social dimension on MAIS was showed with T-statistics score at 2.059, greater than 1.96. Therefore, it was concluded that social dimension significantly effect on MAIS. The original sample value was 0.178 , indicating that the direction of the relationship between the social dimension and MAIS was positive or in the same direction. Based on the statistical results, it was concluded that hypothesis $1\left(\mathrm{H}_{1}\right)$ was accepted.

$\mathbf{H}_{\mathbf{2}}$ The influence of the financial flexibility dimension on MAIS was indicated by the value of Tstatistics of 2,507, greater than 1.96. Therefore, it was concluded that the financial flexibility dimension had a significant effect on MAIS. The original sample value was 0.224 , indicating that the direction of the relationship between the financial flexibility dimension and MAIS was positive or in the same direction. Based on these statistical results, it was concluded that hypothesis $2\left(\mathrm{H}_{2}\right)$ was accepted.

$\mathbf{H}_{3}$ The influence of the environmental dimension on MAIS was indicated by the T-statistics value of 3.389, greater than 1.96. Therefore, it was concluded that the environmental 
Suwondo, O. M., Ratnawati, T., Pudjirahardjo, W. J., \& Nugroho, M. (2018). The Influence of Social Dimension, Financial Flexibility Dimension and Environmental Dimension (Triple Bottom Line) on The Management Accounting Information System in Regional General Hospitals in East Java Province. Archives of Business Research, 6(12), 81-89.

dimension significantly effected MAIS. The original sample value was 0.272 , indicating that the direction of the relationship between the dimensions of financial flexibility and MAIS was positive or in the same direction. Based on these statistical results, it was concluded that hypothesis $3\left(\mathrm{H}_{3}\right)$ was accepted.

\section{CONCLUSION}

1. Social dimension had a significant effect on the Management Accounting Information System of the Regional Public Service Agency (BLUD) in the General Regional Hospitals in East Java Province.

2. The financial flexibility dimension had a significant effect on the Management Accounting Information System of the Regional Public Service Agency (BLUD) in the General Regional Hospitals in East Java Province.

3. The environmental dimension had a significant effect on the Management Accounting Information System of the Regional Public Service Agency (BLUD) in the General Regional Hospitals in East Java Province.

\section{References}

Mulyanto Nugroho. 2018. The Relationship of Shares Ownership, Economic Macro and Company Value Profitability as Mediation Variable (Case Study at Mining Industry who are lited in Bursa Efek Indonesia (BEI). International Journal of Research in Humanities and Social Studies ISSN 2394-6288 (print) * ISSN 2394-6296 (online), Volume 5, Issue 5, pp 1-9.

Newbrander, William. Elizabeth Lewis, 1999; Health Reform and Financing Program \&APHIA Financing and Sustainability Project Management Sciences for Health CONTRACT NO. 623-0264-C-00-7005-00.

Hennan Leyenaar, 1997. Management Accounting for Hospital, special article., Department of Psychiatry, University of Cape Town, and Forensic Psychiatry Unit, Valkenberg Hospital, Cape Town.

Hansen, Don R. and Maryanne M. Mowen (2007), Managerial Accounting 8Th Edition, International Student Edition Thompson South Western.

Kister, Maria Curie. 2015. Sklodowska University, Poland, Hospital Management Support Through the use of Management Accounting, Joint International Conference, 2015. 27-29 May, Bari Italia.

Elkington, John. (1997), Cannibal with Forks, The Triple Bottom Line in The Twentieth Century Business.

Matteson, Michael. and Metivier, Chris. (2015), Three Theories of Corporate Social Responsibility. Chapter 13.2 (http://businessethicsworkshop .com/textbook.html).

Johansson, Sebastian., Anton Karlsson., Christian Hagberg, 2015, Thesis, The relationship between CSR and financial performance, Linnaeus University in Växjö, Sweden.

Chetty, Sukanya., Rebekah Naidoo., Yudhvir Seetharam. 2015., The Impact of Corporate Social Responsibility on Firms' Financial Performance in South Afric., Jurnal Contemporary Economic, University of the Witwatersrand School of Economic and Business Sciences, South Africa.

Butt, Babar Zaheer. 2010. Ahmed Imran Hunjra and Kashif-Ur-Rehman. Financial Management Practices and Their Impact on Organizational Performance. World Applied Sciences Journal 9 (9): 997-1002, 2010 ISSN 1818-4952 (C) IDOSI Publications.

Nishitani, Kimitaka, 2015. An Empirical Analysis of the Effects on Firms' Economic Performance of Implementing Environmental Management Systems, April 2015), (C) Springer Science+Business Media B.V. 2010.

Sudaryanto., Surya Raharja,. 2011. Pengaruh Kinerja Lingkungan Terhadap KinerjaFinansial Perusahaan Dengan CorporateSocial Responsibility (Csr) Disclosure Sebagai Variabel Intervening, Universitas Diponegoro Semarang.

Partners for Health Reform plus (PHRplus), USAID, Management Accounting System For Hospital (MASH, Order No. TK010, 2004.

"Global Reporting Initiative" (GRI), Globalreporting.org. Retrieved 2013-09-24

Kementerian Dalam Negeri, 2007, Peraturan Menteri Dalam Negeri Nomor 61, Tentang Pedoman Teknis Pengelolaan Keuangan Badan Layana Umum Daerah (PPK-BLUD). 
Bouchani, Zahra., Mehrdad Ghanbari, 2015, The relation between financial flexibility and financial performance with the ratio of book value to market value in Tehran listed firms, Department of Accounting, Ilam Science and Research Branch, Islamic Azad University, Ilam, Iran, Journal of Scientific Research and Development 2 (2).2 Department of Accounting, Ilam Branch, Islamic Azad University, Ilam, Iran.

Adisasmito, Wiku. (2014). Sistem Manajemen Lingkungan Rumah Sakit. Jakarta, Rajagrafindo Persada.

Aditama, Tjandra Yoga. 2015, Manajemen Administrasi Rumah Sakit, Penerbit Universitas Indonesia.

Thomson., Buchbiner., and Shank, An overview of Healthcare Management, John and Barlette Learning.

Ghozali, Imam. 2013, Aplikasi Analisis Multivariate dengan Program IBM-SPSS 21, Badan Penerbit Universitas Diponegoro Semarang.

Jogiyanto., Abdillah. 2016. Konsep \& Aplikasi PLS untuk Penelitian Empiris, Edisi pertama, Cetakan ketiga, BPFEYogyakarta. 